\title{
Determination of Maize-Wheat-Soybean Blending Ratio for Improved Nutritional and Process Quality of Bread in Selected Zones of Oromia, Ethiopia
}

\author{
Megersa Daba \\ Oromia Agricultural Research Institute, Addis Ababa, Ethiopia
}

Email address:

megersa2@gmail.com

\section{To cite this article:}

Megersa Daba. Determination of Maize-Wheat-Soybean Blending Ratio for Improved Nutritional and Process Quality of Bread in Selected Zones of Oromia, Ethiopia. International Journal of Science, Technology and Society. Vol. 9, No. 3, 2021, pp. 119-126.

doi: $10.11648 /$ j.ijsts.20211003.12

Received: March 8, 2021; Accepted: May 19, 2021; Published: June 8, 2021

\begin{abstract}
Bread is staple food and its consumption is increasing in Ethiopia. Most of the rural families prepare their daily food from cereal products and do not consider the nutritional aspects of view. Hence, most of the children and mothers in the rural families are affected by malnutrition. Thus, it is essential to consider different methods of food preparations at home level that constitutes sufficient nutrients. Therefore, this study was conducted to determine maize, wheat and soybean blending ratio for improved nutritional and process quality of bread. Study site, farmers and samples (maize, wheat, and soybean varieties) were purposively selected. Proximate, energy and minerals contents were determined with three replications following AOAC methods. Thirteen formulations of composite flour were determined using mixture design with the aid of MINITAB 17 software package. The ingredients were $100 \%$ wheat, $100 \%$ maize and mixture of maize, wheat and soybean ranged from 0 $65 \%, 0-100 \%$ and $0-25 \%$ for maize, wheat and soy bean, respectively. Sensory evaluation was done using 9-point hedonic scales. Results of the study showed a significant difference $(p<0.05)$ in nutrients and sensory quality of bread as the compositions of ingredients were changed. The bread had moisture, ash, protein, crude fat, crude fiber, carbohydrate, energy, iron, zinc and calcium ranged from $7.57-8.75 \%, 0.78-2.14 \%, 9.55-22.75 \%, 1.14-6.55 \%, 2.39-3.93 \%, 58.03-75.75 \%$, $357.22-381.53 \mathrm{Kcal}, 19.39-43.00 \mathrm{ppm}, 12.21-48.32 \mathrm{ppm}$ and $11.85-68.62 \mathrm{ppm}$ respectively. The overall acceptability of bread ranged from neither like nor dislike to like very much. Bread baked from $25 \%, 50 \%$ and $25 \%$ flour of maize, wheat and soybean respectively is recommended for nutrient composition allied with consumers' preferences.
\end{abstract}

Keywords: Bread, Maize, Wheat, Soybean, Nutrient, Sensory and Consumers' Preferences

\section{Introduction}

Bread is one of staple food in the world and prepared by baking cereal flour with addition of other ingredients such as sugar, oil, yeast, egg, water, etc. The consumption of bread is increasing in Ethiopia because of expansion of bread technologies. Rural families are preparing their daily food from cereal products and do not consider the nutritional point of view. Thus, many children and mothers are affecting by malnutrition. But, they have different agricultural products. Therefore, it is essential to consider different methods of food preparations at home level that constitutes sufficient nutrients.

The energy distribution of carbohydrate in the diet of children, women and men from Oromia were 65.6\%, 74.6\% and $65.8 \%$ respectively. While, the energy distribution of protein and fat in the diet of children, women and men from Oromia were $10.4 \%, 9.8 \%$ and $9.7 \%$ and $24.2 \%, 15.8 \%$ and $24.8 \%$ respectively [1]. Thus, the diet of an average Ethiopian consists of foods that are mostly carbohydrate based; therefore there is a need for strategic use of inexpensive high protein resources that complement the amino acid profile of the staple diet in order to enhance their nutritive value.

Maize had second (21\%) and first (31\%) for production and yield respectively and one of staple food especially in maize belt areas. Among the top 25 maize producing districts in Ethiopia, 15 are found in Oromia [2]. Approximately 88\% 
of maize produced in Ethiopia is consumed as food, both as green and dry grain [3]. Maize is the most important staple in terms of calorie intake in rural Ethiopia [3]. Although there is now a substantial amount of composite bread technology available, such breads still require at least $70 \%$ wheat flour to be able to rise and hence, implementation of such precommercial inventions has been limited [4].

Soybean is rich in high quality proteins with balanced amino acids, lipids, minerals and bioactive compounds but is limited in starches $\left[\begin{array}{lll}5 & \& & 6\end{array}\right]$. Wheat flour for bread has starches and functional protein glutens that favor the processing of leavened aerated bread, but is limited in fat and balanced amino acids [7]. Addition of oilseed flour to bread has shown to improve protein quality and overall nutritive value [8]. Soybean is rich in protein with well-balanced amino acid profile, so in search for nutritious food products, it provides an opportunity to be used in baked products such as cookies, bread, pasta, soups and snack foods [9].

Oromia has different topography of land while the lowland areas have limitation of wheat cultivation, and the society need wheat grains for bread preparation from other parts of the country and/or import. This leads to poor bread preparation. However, there are many solutions to improve bread quality and quantity. Since maize is the main crops around the area, the utilization of maize may be increased and the cost of the bread and malnutrition might be minimized. Therefore, the aim of this study, was to select the best nutritious and access consumers preference of maize, wheat and soybean flour mixture of bread

\section{Objectives}

1) To determine the optimum blending ratio with respect to nutritional, processing and sensory qualities, and

2) To evaluate physio-chemical and nutritional qualities of the food item designed.

\section{Materials and Methods}

\subsection{Samples Collection and Processing}

Maize (Zea mays) and soybean seeds (Glycine max) were obtained from Bako Agricultural Research Center of IQQO (Oromia Agricultural Research Institute) while wheat varieties were collected from Sinana Agricultural Research Center. All grain seeds were cleaned, sorted and milled (whole meal flour) by using laboratory miller, but soybean was processed before converted to flour to remove all antinutritional factors according to IITA, 1990 method [10]. Different ratios of maize, soy bean and wheat flour were prepared by using design expert version software.

\subsection{Study Site}

The study was conducted at Bako Tibe and Horo districts which are found in West Showa and Horo Guduru Wollega zones respectively as shown on figure 1. Amarti Gibe and Bacara Oda Gibe peasant association (PA) were selected from Bako Tibe and Didibe Kistana PA was selected from Horo Guduru. From each peasant associations two farmers' research groups having 10-15 members were organized in the study area. Site selection of representative farmers was done with a multi-disciplinary team from the research center and agricultural development agents based on maize production potential and interested host farmers. Laboratory analysis was undertaken at Food Science Research Directorate of IQQO.

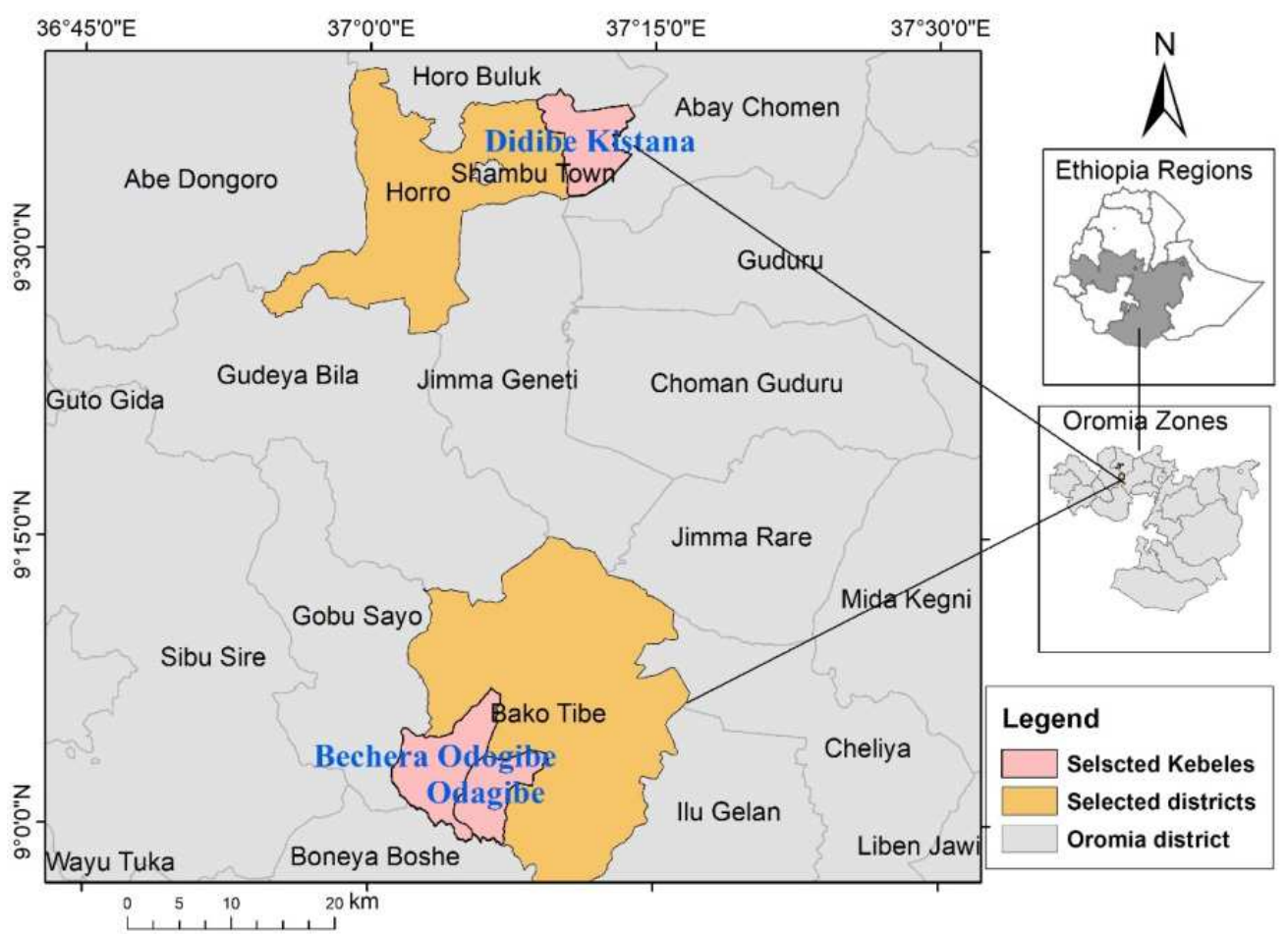

Figure 1. Map of study area. 


\subsection{Blend Formulation}

Blending ratio was determined by expert design using software. Accordingly, 16 treatments with in two control and three replication were implemented. Therefore, only thirteen treatments were reported.

Table 1. Bread treatment and blend (mixture) of maize, wheat and soybean flour ratio.

\begin{tabular}{lllll}
\hline Treatment & Maize (\%) & Wheat (\%) & Soybean (\%) & Code \\
\hline 1 & 65 & 25 & 10 & 1 \\
2 & 54 & 25 & 21 & 2 \\
3 & 65 & 25 & 10 & 3 \\
4 & 48 & 27 & 25 & 4 \\
5 & 25 & 50 & 25 & 5 \\
6 & 56 & 34 & 10 & 6 \\
7 & 25 & 50 & 25 & 7 \\
8 & 38 & 50 & 12 & 8 \\
9 & 45 & 38 & 17 & 9 \\
10 & 43 & 32 & 25 & 10 \\
11 & 49 & 32 & 19 & 11 \\
12 & 34 & 41 & 25 & 12 \\
13 & 33 & 48 & 19 & 13 \\
14 & 38 & 50 & 12 & 14 \\
15 & 100 & 0 & 0 & 15 \\
16 & 0 & 100 & 0 & 16 \\
\hline
\end{tabular}

\subsection{Bakery Study}

Straight dough making method was followed for baking bread. Equal amount of ingredients [(sugar $(2 \mathrm{~g})$, salt $0.5 \mathrm{~g}$, yeast $(2 \mathrm{~g})$ and water $120 \mathrm{ml})$ ] were used for baking bread per 100 gram of flour mixture as shown on the Table 1.

\subsection{Determination of Nutrient Compositions}

Proximate Composition: Moisture, protein and fat content of the grain samples and proximate composition of bread blends were determined by using the AOAC, 1990 methods [11]. Total carbohydrate is calculated by difference. Energy was calculated using Artwater factor: Fat x $9+$ Carbohydrate $\mathrm{x} 4$ + Protein $\mathrm{x} 4$ (kcal).

Minerals: Iron, zinc and calcium content were analyzed by using AOAC Official Method 975.03 [12]. All determinations were carried out in triplicate.

\subsection{Sensory Evaluation of Bread}

Bread samples prepared from different mixture of maize, wheat and soybean flour were evaluated by twenty eight panelists consisting of researchers, selected farmers and development agents. Finally, the study had training and practical demonstration for farmers and development agents. The panelists were requested to evaluate the bread on the basis of acceptance of its shape (appearance), color, texture, odor, taste and overall acceptability qualities by using 9 Hedonic scale with 1 representing dislike extremely and 9 the highest which is like extremely.

\subsection{Data Analysis}

Mean and standard deviations were calculated for proximate, minerals and acceptability of the sensory attributes. All recorded data were subjected to SAS software to test ANOVA and the mean was separated by list significant different.

\section{Results and Discussions}

\subsection{Proximate and Energy Composition of Bread Samples}

Proximate and energy content of different maize, wheat and soybean flour mixture of bread shown on Table 2. There was significant difference $(p<0.05)$ in the proximate and energy composition of formulated bread samples. The mean moisture, ash, protein, crude fat and fiber, carbohydrate and energy composition of formulated bread samples were $8.11 \%, 1.36 \%$, $18.33 \%, 4.06 \%, 64.84 \%$ and $369.34 \mathrm{kcal}$ respectively. The moisture content of the bread has the least $(7.57 \%)$ for blend $48 / 27 / 25$ ratio while the highest $(8.75 \%)$ was from maize bread (100\% maize flour). The least ash and crude fat was obtained from wheat bread $(100 \%$ wheat flour) with value of $0.78 \%$ and $1.14 \%$ respectively. The maximum ash content $(2.14 \%)$ and crude fat $(6.49 \%)$ was found in $25 / 50 / 25$ and $48 / 27 / 25$ flour mixture bread samples respectively. the maximum and minimum protein content $22.75 \%$ and $9.55 \%$ found in $48 / 27 / 25$ flour mixture bread and maize bread samples respectively. The protein content was not significant among 48/27/25, 25/50/25, $43 / 32 / 25,49 / 32 / 19$ and $34 / 41 / 25$ bread samples. The crude fiber content ranged from $2.39-3.93 \%$. The bread prepared from $25 / 50 / 25$ and 65/25/10 maize, wheat and soybean ratio respectively had the least and highest crude fiber. Dietary fibre in cereals is derived principally from the plant cell walls and can best be defined analytically as lignin and non-starch polysaccharide. This includes all polysaccharides other than alinked glucose polymers [13]. Anderson reported different ratio of dietary fiber content for different types of wheat flour bread. Accordingly, whole meal, brown and white wheat bread contained $8-9 \mathrm{~g}, 5-6 \mathrm{~g}$ and $2-3 \mathrm{~g}$ of dietary fiber/100g bread respectively. The concentration of carbohydrate and energy of formulated bread ranged from $58.03-75.75 \%$ and 357.22 $382.29 \mathrm{Kcal}$ respectively. The maximum carbohydrate and energy were obtained from whole maize bread and 25/50/25 maize, wheat and soybean ratio of bread respectively.

The protein content of maize $(\mathrm{N}=6)$, wheat $(\mathrm{N}=2)$ and soybean grain $(\mathrm{N}=3)$ was obtained with the values of $8.5 \%$, $13.1 \%$ and $34.94 \%$ and for fat $3.96 \%, 3.03 \%$ and $20.11 \%$ respectively. While, the mean formulated bread had $18.33 \%$ and $4.03 \%$ of protein and fat respectively. This result is in agreement with FAO's report which was the energy, protein and fat contents in $100 \mathrm{~g}$ edible portion of bread white, maize whole flour and soybean dried raw bread white: $261,7.7,2.0$, whole flour maize: 353, 9.3, 3.8, soybean: 416, 36.5, 20.0 [14]. Eyele et al. also reported the composite dried bread flours processed from wheat, cassava and soybean had moisture, crude fiber, protein, fat, ash, total carbohydrate and energy contents in the 
range of $4.87-6.15 \%, 2.68-4.00 \%, 13.05-21.2 \%, 4.96-11.25 \%$, $3.78-4.23 \%, 53.17-70.21 \%$ and $389.6-414.73 \mathrm{kcal} / 100 \mathrm{~g}$, respectively [15]. It is similar with this finding except energy which was lower in this study because mainly the protein, fat and energy source were from soybean flour and Eyele et al. (2017) have used up to $30 \%$ of soybean during bread formulation. Thomison et al. (2004) also reported maize grain protein and fat concentration averaged for three years across hybrids maize were $8.7 \%$ and $6.3 \%$ respectively [16].

\subsection{Some Minerals Composition of Bread Samples}

Iron $(\mathrm{Fe}), \mathrm{Zinc}(\mathrm{Zn})$ and Calcium $(\mathrm{Ca})$ contents of bread are shown on table 3 . The iron values of the bread ranged from $13.11 \mathrm{ppm}$ to $43.00 \mathrm{ppm}$. The wheat bread (100\% wheat flour) had the highest $\mathrm{Fe}$ compositions which was significantly $(\mathrm{p}<0.05)$ different among other samples, except 33//48/19 and 34/41/25 maize, wheat and soybean flour ratio respectively. The least Fe contents was from $48 / 27 / 25$ with value of $13.11 \mathrm{ppm}$. The highest and least $\mathrm{Ca}$ content recorded from $34 / 41 / 25$ and maize (100\% maize) bread sample with value of $68.62 \mathrm{ppm}$ and $11.85 \mathrm{ppm}$ respectively. This might be attributed to the high percentage of wheat and soybeans, as soybeans seeds were reported to contain appreciable amounts of minerals [17].

Table 2. Proximate and Minerals content of Maize-wheat-soybean bread at dry basis.

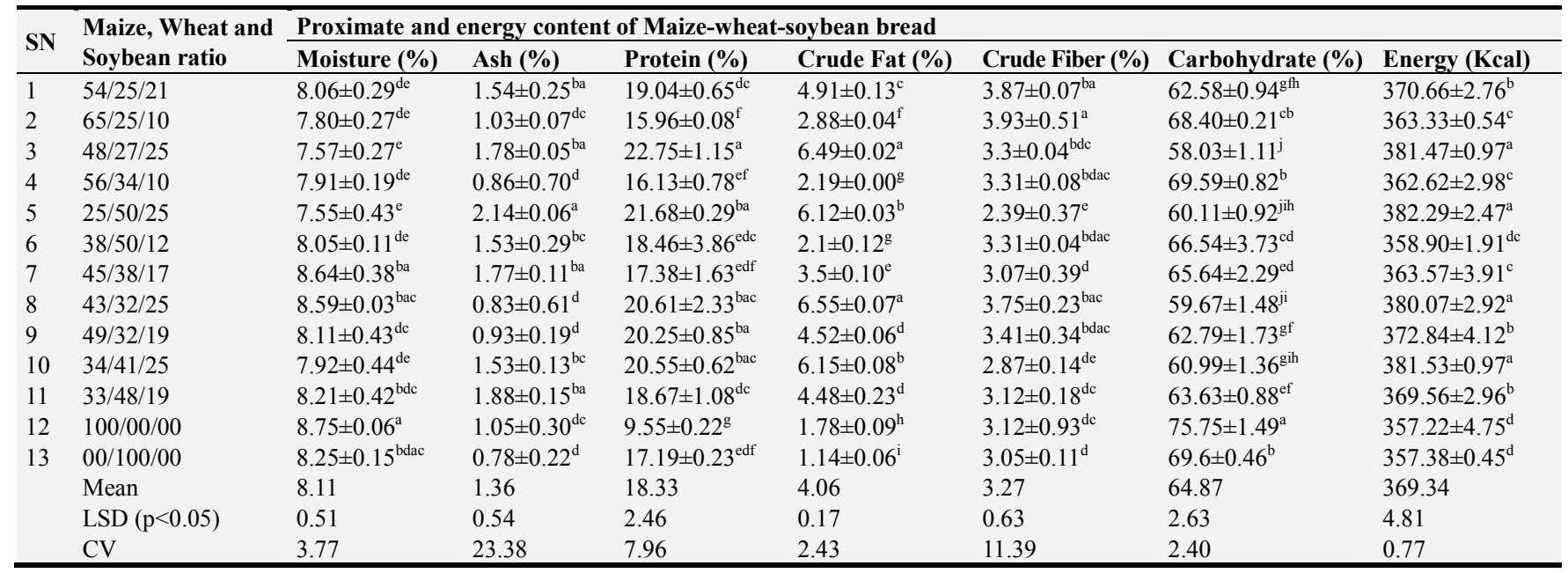

Note: In each column means followed by different letters (a, b, c, d, e, etc.) are significantly different at $\alpha<0.05$.

Table 3. Some Minerals content of Maize-wheat-soybean bread at dry basis.

\begin{tabular}{|c|c|c|c|c|}
\hline \multirow{2}{*}{ S. Number } & \multirow{2}{*}{$\begin{array}{l}\text { Maize, Wheat and } \\
\text { Soybean ratio }(\%)\end{array}$} & \multicolumn{3}{|c|}{ Minerals content of Maize-wheat-soybean bread at dry basis } \\
\hline & & Fe (ppm) & Zn (ppm) & Ca (ppm) \\
\hline 1 & $54 / 25 / 21$ & $19.39 \pm 1.08^{\mathrm{f}}$ & $34.78 \pm 2.10^{\mathrm{f}}$ & $55.03 \pm 2.55^{\mathrm{e}}$ \\
\hline 2 & $65 / 25 / 10$ & $21.91 \pm 0.32^{\mathrm{f}}$ & $34.60 \pm 1.10^{\mathrm{f}}$ & $36.32 \pm 1.31^{\mathrm{h}}$ \\
\hline 3 & $48 / 27 / 25$ & $13.11 \pm 1.19^{\mathrm{g}}$ & $12.21 \pm 1.51^{\mathrm{h}}$ & $19.41 \pm 2.63^{\mathrm{i}}$ \\
\hline 4 & $56 / 34 / 10$ & $33.11 \pm 0.62^{\mathrm{d}}$ & $39.00 \pm 2.47^{\mathrm{e}}$ & $36.45 \pm 0.30^{\mathrm{h}}$ \\
\hline 5 & $25 / 50 / 25$ & $37.53 \pm 1.27^{\mathrm{c}}$ & $46.82 \pm 0.44^{\text {ba }}$ & $64.23 \pm 1.46^{\mathrm{b}}$ \\
\hline 6 & $38 / 50 / 12$ & $27.80 \pm 3.35^{\mathrm{e}}$ & $43.36 \pm 1.21^{\mathrm{bdc}}$ & $49.65 \pm 0.89^{f}$ \\
\hline 8 & $43 / 32 / 25$ & $37.50 \pm 0.84^{c}$ & $42.85 \pm 0.97^{\mathrm{dc}}$ & $60.97 \pm 1.86^{\mathrm{c}}$ \\
\hline 9 & $49 / 32 / 19$ & $31.50 \pm 4.01^{\mathrm{d}}$ & $42.30 \pm 256^{\mathrm{ed}}$ & $51.65 \pm 1.82^{\mathrm{e}}$ \\
\hline 10 & $34 / 41 / 25$ & $40.92 \pm 1.25^{\text {ba }}$ & $48.32 \pm 3.11^{\mathrm{a}}$ & $68.62 \pm 0.34^{\mathrm{a}}$ \\
\hline 11 & $33 / 48 / 19$ & $42.17 \pm 1.47^{\mathrm{ab}}$ & $46.26 \pm 1.44^{\mathrm{bac}}$ & $58.91 \pm 1.20^{\mathrm{dc}}$ \\
\hline 12 & $100 / 00 / 00$ & $20.25 \pm 0.82^{f}$ & $27.44 \pm 4.39$ & $11.85 \pm 2.35^{\mathrm{j}}$ \\
\hline \multirow[t]{3}{*}{13} & $00 / 100 / 00$ & $43.00 \pm 3.16^{\mathrm{a}}$ & $48.17 \pm 2.72^{\mathrm{a}}$ & $41.96 \pm 0.46^{\mathrm{g}}$ \\
\hline & Mean & 31.33 & 39.43 & 47.04 \\
\hline & $\mathrm{CV}$ & 6.34 & 5.69 & 3.57 \\
\hline
\end{tabular}

Note: In each column means followed by different letters (a, b, c, d, e, etc.) are significantly different at $\alpha<0.05$.

\subsection{Sensory Evaluation}

The sensory data for bread quality attributes are presented in Table 4. All sensory quality attributes (shape, color, texture, Taste, odor and overall acceptability) of bread ranged from neither like nor dislike to like very much. The preference mean value of $7.25,7.05,6.73,6.56,6.47$ and
7.13 awarded for shape, color, texture, taste, odor and overall acceptability among bread samples recorded respectively. There was significant difference $(\mathrm{p}<0.05)$ in the shape, color, texture, taste, odor and overall acceptability among bread samples. The study revealed that the highest ratio of maize flour were less preferred for sensory scores and maize bread (100\% maize flour) had the least preferred for shape, color, 
texture, taste, odor and overall acceptability. While wheat bread had the most preferred for shape, color, texture, Taste, odor and overall acceptability. However, the overall acceptability of wheat bread was not significant among
25/50/25, 56/34/10,38/50/12 and 33/48/19 maize, wheat and soybean flour mixtures respectively. The result revealed that the $25 / 50 / 25,33 / 48 / 19$, and $0 / 100 / 0$ bread samples were among best preferred for all bread quality attributes.

Table 4. Bread sensory qualities score for bread experiment.

\begin{tabular}{|c|c|c|c|c|c|c|c|}
\hline \multirow{2}{*}{ SN } & \multirow{2}{*}{$\begin{array}{l}\text { Maize, wheat and soybean flour } \\
\text { ratio respectively }(\%)\end{array}$} & \multicolumn{6}{|c|}{ Bread sensory qualities } \\
\hline & & Shape & Color & Texture & Taste & Odor & Overall acceptability \\
\hline 1 & $54 / 25 / 21$ & $6.89 \pm 1.83^{\mathrm{efg}}$ & $6.18 \pm 1.85^{\mathrm{ef}}$ & $5.93 \pm 2.00^{\mathrm{efg}}$ & $5.50 \pm 2.13^{\text {hi }}$ & $5.61 \pm 1.99^{\mathrm{fg}}$ & $6.79 \pm 1.29^{\operatorname{defg}}$ \\
\hline 2 & $65 / 25 / 10$ & $6.61 \pm 1.40^{\text {efgh }}$ & $6.43 \pm 1.55^{\mathrm{def}}$ & $6.46 \pm 1.37^{\mathrm{def}}$ & $6.36 \pm 1.75^{\operatorname{defgh}}$ & $5.71 \pm 1.94^{\text {defg }}$ & $6.68 \pm 1.28^{\mathrm{fg}}$ \\
\hline 3 & $48 / 27 / 25$ & $6.36 \pm 1.45^{\mathrm{gh}}$ & $6.14 \pm 1.67^{\mathrm{f}}$ & $5.71 \pm 1.98^{\mathrm{fg}}$ & $5.57 \pm 1.89^{\text {ghi }}$ & $6.04 \pm 2.15^{\text {cdefg }}$ & $6.54 \pm 1.75^{\mathrm{gh}}$ \\
\hline 4 & $25 / 50 / 25$ & $8.57 \pm 0.84^{\mathrm{a}}$ & $7.86 \pm 1.33^{\mathrm{a}}$ & $7.93 \pm 1.25^{\mathrm{a}}$ & $7.21 \pm 1.73^{\mathrm{abcd}}$ & $7.00 \pm 1.70^{\mathrm{ab}}$ & $7.50 \pm 1.67^{\text {abcde }}$ \\
\hline 5 & $56 / 34 / 10$ & $7.82 \pm 1.44^{\mathrm{abc}}$ & $7.39 \pm 1.75^{\mathrm{abc}}$ & $6.89 \pm 2.04^{\text {bcd }}$ & $7.07 \pm 1.70^{\text {bcde }}$ & $6.75 \pm 2.01^{\mathrm{bc}}$ & $7.61 \pm 1.40^{\mathrm{abc}}$ \\
\hline 7 & $45 / 38 / 17$ & $6.50 \pm 2.29^{\mathrm{fgh}}$ & $6.50 \pm 2.30^{\mathrm{def}}$ & $6.61 \pm 1.91^{\text {cde }}$ & $6.79 \pm 2.50^{\text {bcdef }}$ & $6.54 \pm 2.36^{\text {bcde }}$ & $6.89 \pm 2.18^{\text {cdefg }}$ \\
\hline 8 & $43 / 32 / 25$ & $7.00 \pm 1.72^{\text {defg }}$ & $7.21 \pm 1.55^{\mathrm{abcd}}$ & $6.75 \pm 1.65^{\mathrm{bcd}}$ & $6.39 \pm 1.69^{\text {cdefgh }}$ & $6.43 \pm 1.95^{\text {bcdef }}$ & $6.93 \pm 1.86^{\text {cdefg }}$ \\
\hline 9 & $49 / 32 / 19$ & $6.82 \pm 1.66^{\mathrm{efg}}$ & $7.04 \pm 1.40^{\text {bcd }}$ & $6.43 \pm 1.14^{\mathrm{def}}$ & $6.29 \pm 1.74^{\text {efgh }}$ & $6.36 \pm 1.91^{\text {bcdef }}$ & $6.75 \pm 1.55^{\text {defg }}$ \\
\hline 10 & $34 / 41 / 25$ & $6.75 \pm 1.43^{\mathrm{efg}}$ & $6.86 \pm 1.76^{\mathrm{a}}$ & $6.50 \pm 1.60^{\text {cdef }}$ & $5.93 \pm 1.98^{\text {fghi }}$ & $5.68 \pm 1.89^{\mathrm{efg}}$ & $6.71 \pm 1.74^{\mathrm{efg}}$ \\
\hline 11 & $33 / 48 / 19$ & $8.21 \pm 1.20^{\mathrm{ab}}$ & $7.89 \pm 1.29^{\mathrm{ab}}$ & $7.54 \pm 1.69^{\mathrm{ab}}$ & $7.29 \pm 1.74^{\mathrm{abc}}$ & $7.21 \pm 1.37^{\mathrm{ab}}$ & $7.79 \pm 1.60^{\mathrm{ab}}$ \\
\hline 12 & $100 / 0 / 0$ & $5.93 \pm 1.90^{\mathrm{h}}$ & $6.82 \pm 2.04^{\mathrm{h}}$ & $5.54 \pm 1.73^{\mathrm{g}}$ & $5.21 \pm 1.91^{\mathrm{i}}$ & $5.43 \pm 2.28^{\mathrm{g}}$ & $5.86 \pm 2.19^{\mathrm{h}}$ \\
\hline \multirow[t]{3}{*}{13} & $0 / 100 / 0$ & $8.54 \pm 0.79^{\mathrm{a}}$ & $7.71 \pm 1.12^{\mathrm{ab}}$ & $8.00 \pm 1.28^{\mathrm{a}}$ & $8.11 \pm 1.47^{\mathrm{a}}$ & $7.86 \pm 1.60^{\mathrm{a}}$ & $8.18 \pm 1.94^{\mathrm{a}}$ \\
\hline & $\mathrm{CV}$ & 20.4 & 21.83 & 22.49 & 25.99 & 26.14 & 21.44 \\
\hline & $\operatorname{LSD}(\alpha=0.05)$ & 0.76 & 0.81 & 0.80 & 0.90 & 0.89 & 0.80 \\
\hline
\end{tabular}

Note: In each column means followed by different letters (a, b, c, d, e, etc.) are significantly different at $\alpha<0.05$.

\subsection{Correlation Coefficients of Bread Sensory Qualities with Their Proximate, Energy and Minerals Content}

Table 5. Person correlation coefficients of bread sensory qualities with their proximate, energy and minerals content.

\begin{tabular}{|c|c|c|c|c|c|c|c|c|c|c|c|c|c|c|c|c|}
\hline $\begin{array}{l}\text { Bread } \\
\text { quality } \\
\text { indicators }\end{array}$ & Shape & Color & Texture & Taste & Odor & OAA & MC & Ash & Protein & Fiber & Fat & СНО & Energy & $\mathrm{Fe}$ & Zn & $\mathrm{Ca}$ \\
\hline Shape & 1.00 & $0.66^{* * * *}$ & $0.62 * * * *$ & $0.55^{* * * *}$ & $0.49 * * * *$ & $0.59 * * * *$ & $-0.36^{*}$ & 0.08 & 0.25 & -0.19 & -0.02 & -0.13 & 0.07 & 0.27 & 0.32 & $0.35^{*}$ \\
\hline Color & & 1.00 & $0.63^{* * * *}$ & $0.50 * * * *$ & $0.46^{* * * * *}$ & $0.59 * * * *$ & 0.31 & -0.10 & $-0.36^{*}$ & 0.13 & $-0.33^{*}$ & $0.34^{*}$ & $-0.38^{*}$ & 0.14 & 0.29 & 0.04 \\
\hline Texture & & & 1.00 & $0.63 * * * *$ & $0.55^{* * * * *}$ & $0.58 * * * *$ & -0.18 & -0.09 & $0.37 *$ & -0.18 & 0.08 & -0.24 & 0.17 & $0.44 * *$ & $0.34 *$ & $0.40^{*}$ \\
\hline Taste & & & & 1.00 & $0.67 * * * *$ & $0.58 * * * *$ & 0.06 & 0.02 & 0.05 & -0.19 & -0.08 & 0.01 & -0.06 & $0.46^{* *}$ & $0.41 * *$ & $0.36^{*}$ \\
\hline Odor & & & & & 1.00 & $0.67 * * * *$ & -0.01 & -0.05 & 0.07 & -0.23 & -0.04 & -0.01 & 0.03 & $0.38 *$ & $0.39 *$ & $0.32^{*}$ \\
\hline OAA & & & & & & 1.00 & 0.16 & -0.10 & -0.13 & -0.19 & $-0.33^{*}$ & -0.23 & -0.28 & $0.42 * *$ & $0.45^{*}$ & 0.23 \\
\hline $\mathrm{MC}$ & & & & & & & 1.00 & -0.25 & $-0.43 * *$ & 0.17 & -0.29 & $0.32 *$ & $-0.45^{* *}$ & 0.20 & 0.17 & -0.04 \\
\hline Ash & & & & & & & & 1.00 & 0.30 & -0.26 & $0.42 * *$ & $-0.42 * *$ & 0.29 & -0.04 & -0.01 & 0.25 \\
\hline Protein & & & & & & & & & 1.00 & -0.07 & $0.73 * * * *$ & $-0.95 * * * *$ & $0.74 * * * *$ & 0.13 & 0.09 & $0.53^{* * *}$ \\
\hline Fiber & & & & & & & & & & 1.00 & -0.06 & -0.02 & -0.24 & $-0.42 * *$ & -0.21 & -0.16 \\
\hline Fat & & & & & & & & & & & 1.00 & $-0.89 * * * *$ & $0.95 * * * *$ & -0.00 & -0.11 & $0.45^{* *}$ \\
\hline $\mathrm{CHO}$ & & & & & & & & & & & & 1.00 & $-0.83^{* * * * *}$ & 0.06 & -0.02 & $-0.54 * * *$ \\
\hline $\mathrm{Fe}$ & & & & & & & & & & & & & & 1.00 & $0.86^{* * * *}$ & $0.68 * * * *$ \\
\hline $\mathrm{Zn}$ & & & & & & & & & & & & & & & 1.00 & $0.79 * * *$ \\
\hline $\mathrm{Ca}$ & & & & & & & & & & & & & & & & 1.00 \\
\hline
\end{tabular}

Where, $\mathrm{OAA}=$ Overall acceptability, $\mathrm{CHO}=$ Carbohydrate, $* * * *=\mathrm{P}<0.0001, * * *=\mathrm{P}<0.0005, * *=\mathrm{P}<0.01$ and $*=\mathrm{P}<0.05$

The correlation coefficients of bread sensory qualities with their proximate, energy and minerals content is presented on Table 5. Accordingly, all bread sensory qualities were positively correlated to each other and strongly significant $(\mathrm{P}<0.0001)$. Moisture content was negatively correlated to shape and energy and significant $(\mathrm{P}<0.05)$. However, it was positively correlated with carbohydrate and significant $(\mathrm{P}<0.05)$. Ash content was positively correlated to crude fat and significant $(\mathrm{P}<0.01)$ but negatively correlated to carbohydrate and significant $(\mathrm{P}<0.01)$. Protein content was negatively correlated to color, moisture content and carbohydrate. It was significant $(\mathrm{P}<0.05)$ for color and moisture but strongly significant $(\mathrm{P}<0.0001)$ for carbohydrate. Protein content was positively correlated to crude fat, energy and calcium and strongly significant $(\mathrm{P}<0.001)$ for the first two qualities but significant $(\mathrm{P}<0.0005)$ for calcium.

Even though crude fiber content was negatively correlated 
most bread qualities except color and moisture; it was only significant $(\mathrm{P}<0.01)$ for iron. Crude fat content was negatively correlated to color, overall acceptability and carbohydrate and significant $(\mathrm{P}<0.05), \quad(\mathrm{P}<0.05)$ and $(\mathrm{P}<0.0001)$ respectively. Crude fat also positively correlated to ash, energy and calcium significant $(\mathrm{P}<0.01),(\mathrm{P}<0.0001)$ and $(\mathrm{P}<0.01)$ respectively $(\mathrm{P}<0.005)$. Carbohydrate was positively correlated to moisture and significant $(\mathrm{P}<0.05)$. But negatively correlated to energy and Calcium and significant $(\mathrm{P}<0.0001)$ and $(\mathrm{P}<0.0005)$ respectively. Energy was positively correlated to calcium and significant $(\mathrm{P}<0.01)$. Iron was positively correlated to texture, taste, odor, $\mathrm{Zn}$ and $\mathrm{Ca}$ and significant $(\mathrm{P}<0.01),(\mathrm{P}<0.01),(\mathrm{P}<0.05),(\mathrm{P}<0.0001)$ and $(\mathrm{P}<0.0001)$ respectively. Zinc was positively correlated to texture, taste, odor, overall acceptability, and $\mathrm{Ca}$ and significant $(\mathrm{P}<0.05), \quad(\mathrm{P}<0.01), \quad(\mathrm{P}<0.05), \quad(\mathrm{P}<0.05) \quad$ and $(\mathrm{P}<0.0001)$ respectively. Calcium was positively correlated to shape, texture and odor and significant $(\mathrm{P}<0.05)$.

Among bread mixture of maize, wheat and soybean flour studied; mixture of 48/27/25, 25/50/25, and 49/32/29 ratio of maize, wheat and soybean respectively had the highest protein, crude fat and energy. While, bread mixture of maize, wheat and soybean $0 / 100 / 100,33 / 48 / 19$ and 25/50/25 respectively were most preferred. Major Ethiopian food is from carbohydrate based [1] and the selection of bread prepared from different ratio of maize, wheat and soybean could be focus on best nutritious food with protein and energy advantages. Similarly, the selection should be agreed with the consumers' preferences. As shown on the figure 2 the maximum protein was obtained from $48 / 27 / 25$ bread but the highest accepted bread was from $100 \%$ wheat bread. While the maximum energy was obtained from $25 / 50 / 25$ maize, wheat and soybean flour bread samples as illustrated on figure 3.

Different researchers recommended different amount of soybean flour which ranged from $7 \%$ up $30 \%$ to produce acceptable bread with quality attributes similar to $100 \%$ wheat flour [18, $19 \& 20]$. Food that contain large amounts of micronutrients compared to their energy content are called nutrient rich or nutrient dense food. They are preferred as they help in ensuring that diet provides all nutrients needed. Hence, the formulated bread had good source of carbohydrate, protein, fat, fiber, minerals and energy. Therefore, bread prepared from $25 \%, 50 \%$ and $25 \%$ flour of maize, wheat and soybean flour respectively(figure 4) had coincide with nutrition and sensory qualities parameters.

Daily recommended intakes for energy, protein, iron and zinc for children (1-3 years and $12 . \mathrm{kg}$ body weight are $1022 \mathrm{kcal}, 14.0 \mathrm{~g}, 6 \mathrm{mg}, 8.4 \mathrm{mg}$ and for women $(18-59$ years old and $55 \mathrm{~kg}$ body weight) are $2408 \mathrm{kcal}, 41,29 / 11 \mathrm{c} \mathrm{mg}$ and $9.8 \mathrm{mg}$ respectively [21]. To satisfy the daily recommended intake of protein 100 gram of $25 \%, 50 \%$, and $25 \%$ of maize, wheat and soybean flour bread is enough for children but $200 \mathrm{~g}$ bread is recommended for women.

\section{Protein (\%) and Over All Acceptability}

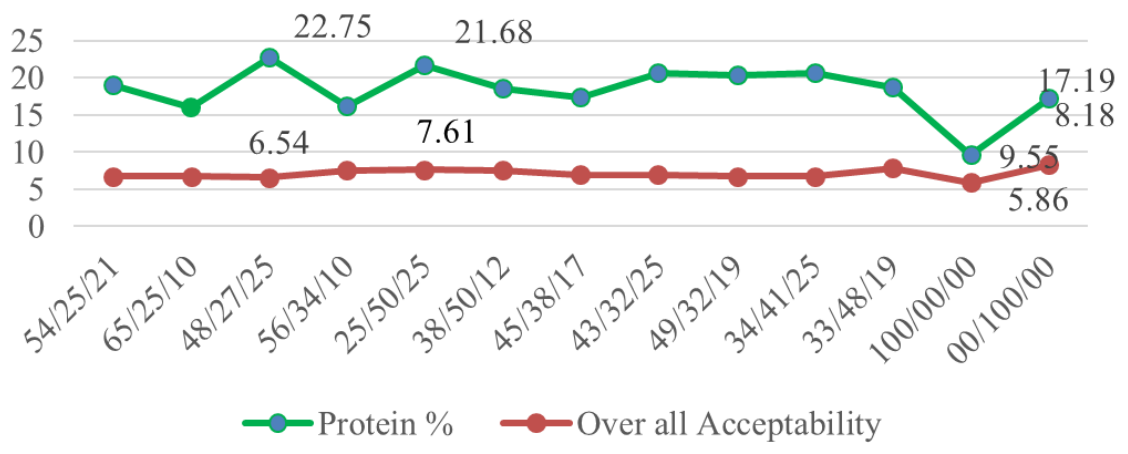

Figure 2. Comparison of highest protein content and overall acceptability among bread prepared.

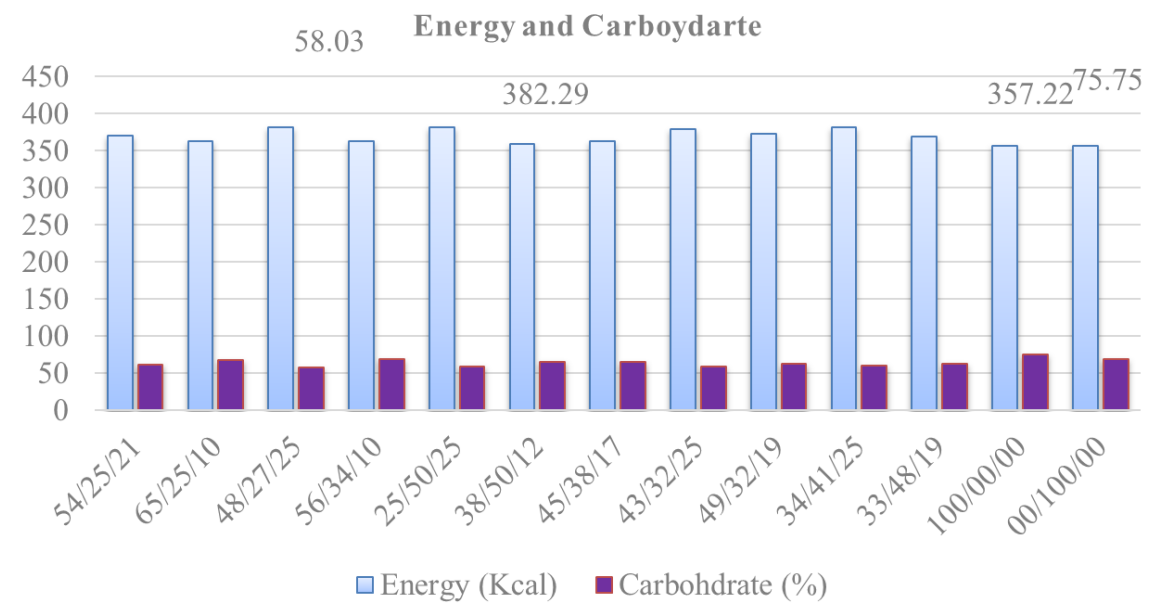

Figure 3. Comparison of highest energy and carbohydrate content among bread prepared. 

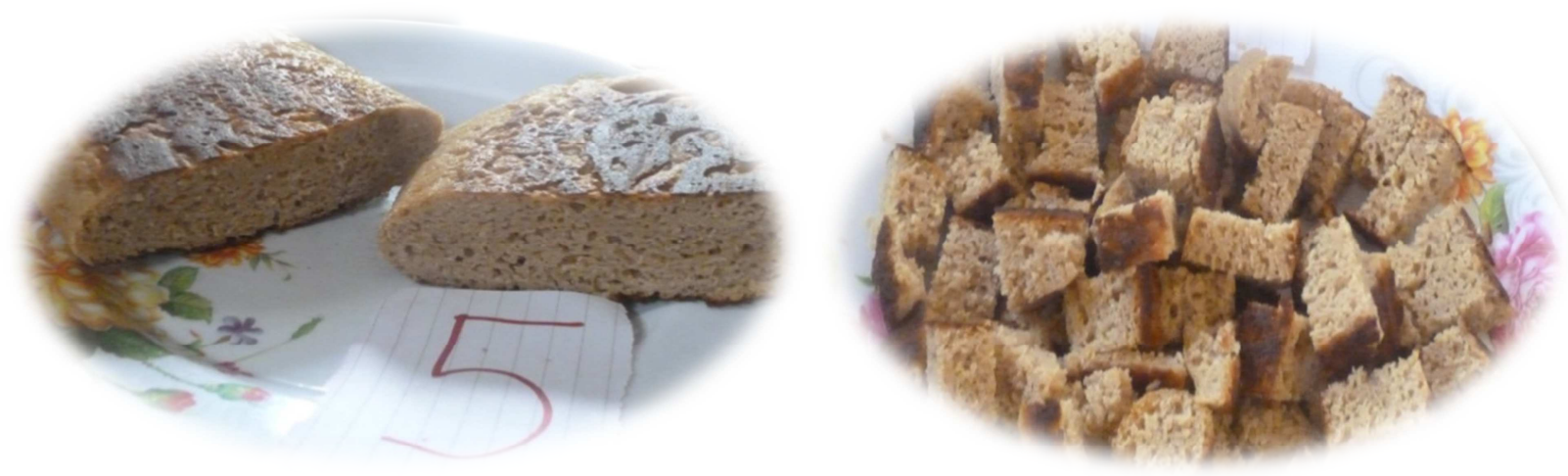

Figure $4.25 \%, 50 \%$, and $25 \%$ of maize, wheat and soybean flour bread.

\section{Conclusion and Recommendations}

This finding revealed that maize, wheat and soybean blending ratio for bread preparation affected both nutrition and consumers' preference. Bread prepared from those mixture superior in nutrients and energy and equivalent to wheat bread for preferences. Bread baked from 25\%, 50\% and $25 \%$ flour of maize, wheat and soybean respectively recommended for nutrient composition allied with consumers' preferences. Substitution of wheat by maize and soybean enhance the proximate and minerals composition but there was a gap on consumers' preference for bread with high protein contents which is very important in study area. Therefore, training for attitude and custom for protein utilization in order to decrease malnutrition is important in the study area.

\section{Acknowledgements}

I would like to thank Food Science Research Directorate Staff for whole hearted support from the beginning up end and as well as Sinana Agricultural Research Center and Bako Agricultural Research Center for their samples provision. Authors' special thanks goes to IQQO-Agricultural Growth Program II for financial support and unserved technical backups.

\section{References}

[1] Ethiopian Puplic Health Institute, 2013. Ethiopian National Food Consumption Survey. Addis Ababa, Ethiopia.

[2] James Warner, Tim Stehulak Leulsegged Kasa, 2015. WoredaLevel Crop Production Rankings in Ethiopia: A Pooled Data Approach. International Food Policy Research Institute (IFPRI) Addis Ababa, Ethiopia.

[3] Tsedeke A, Bekele S, Abebe M, Dagne W, Yilma K, Kindie T, Menale K, Gezahegn B, Berhanu T and Tolera Keno 2015. Factors that transformed maize productivity in Ethiopia. Food Sec. (2015) 7:965-981.

[4] Eggleston G, Omoaka PF, Thedioha DO (1992). Development and Evaluation of products from cassava flour as new alternatives to wheaten breads. J. Food Sci. Agric. Vol. 59:

\section{$377-385$.}

[5] Amarjeet K, Sidhu JS, Singh B (1995). Effect of enzyme active Soya flour and sodium streroyl -2-lactylate additions on white bread making properties. Chem. Microbial. Technol. Lebensm 17 (314: 105-109.

[6] FAO/WHO. 1973. Energy and protein requirements: Report of a joint FAO/WHO ad hoc expert committee. FAO Nutrition Meetings Report Series No. 52. WHO Technical Report Series No. 522. Rome. P. 118.

[7] Becker R, (1981). A compositional study of amaranth grain. J. Food Sci. 46: 1175-1180.

[8] Bressani R, Sanchez-Marroquin A, Morales E (1992). Chemical composition of grain amaranth cultivars and effects of processing on their nutritional quality. Food Rev. Int. 8 (1): 23-49.

[9] Edema MO, Sanni LO, Sanni AI (2005). Evaluation of maizesoybean flour blends for sour maize bread production in Nigeria. Afr. J. Biotechnol. 4 (9): 911-918.

[10] IITA, Ibadan (1990). Soybeans for good health: How to grow and use Soybeans in Nigeria. IITA publication. ISBN 978131 0693. p. 23.

[11] AOAC (1990). Official Methods of Analysis. 15th Edn. Association of Official Analytical Chemists Washington, DC, USA.

[12] AOAC Official Method 975.03. Metals in Plants and Pet Foods Atomic Absorption Spectrophotometric Method. Final Action 1988.

[13] Anderson, J. W. and Ward. K., 1979. High carbohydrate, high fibre diets for insulin-treated men with diabetes mellitus. Anu'ricau Journal of clinical Nutrition. 32, 2312-2321.

[14] FAO. 1993. Food and nutrition in the management of group feeding programmes. Rome

[15] Haimanot H. Ayele, Geremew Bultosa, Tilahun Abera and Tessema Astatkie. Nutritional and sensory quality of wheat bread supplemented with cassava and soybean flours. Cogent Food \& Agriculture (2017), 3: 1331892. https://doi.org/10.1080/23311932.2017.1331892

[16] Thomison PR, Geyer AB, Bishop BL, Young JR, Lentz E (2004) Nitrogen fertility effects on grain yield, protein, and oil of corn hybrids with enhanced grain quality traits, Crop Management 3:1. 
[17] Oluwafemi Gbenga Isaac, Seidu Kudirat Titilope. Quality Evaluation of Composite Bread Produced from Wheat, Cassava, Plantain, Corn and Soy-bean Flour Blends. American Journal of Food Science and Nutrition. Vol. 4, No. 4, 2017, pp. $42-47$.

[18] Dhingra, S., \& Jood, S. (2004). Effect of flour blending on functional, baking and organoleptic characteristics of bread. International Journal of Food Science and Technology, 39, 213-222. https://doi.org/10.1046/j.0950-5423.2003.00766.x

[19] Shao, S., Duncan, A. M., Yang, R., Marcone, M. F., Rajcan, I., \& Tsao, R. (2009). Tracking isoflavones: From soybean to soy flour, soy protein isolates to functional soy bread. Journal of
Functional Foods, 1, https://doi.org/10.1016/j.jff.2008.09.013

[20] Shogren, R. L., Mohamed, A. A., \& Carriere, C. J. (2003). Sensory Analysis of whole wheat/soy flour breads. Journal of Food Science, 68, 2141-2145. https://doi.org/10.1111/jfds.2003.68.issue-6

[21] FAO. 2004. Energy in human nutrition. Report of joint FAO/WHO/UN Expert Consultation. FAO Food and Nutrition Technical Paper Series, No 1. Rom. 